\title{
MODEL EVALUASI DIRI SEKOLAH MENENGAH KEJURUAN DI DAERAI ISTIMEWA YOGYAKARTA
}

\author{
Nuchron, Soenarto, FX. Sudarsono \\ Fakultas Teknik Universitas Negeri Yogyakarta \\ nuchron@yahoo.com
}

\begin{abstract}
Abstrak
Penelitian ini bertujuan mengembangkan model evaluasi diri yang efektif dan dapat memberikan hasil yang akurat dan menunjukkan kelebihan dan manfaat untuk pengambilan keputusan pengembangan. Penelitian dilaksanakan di 8 SMK di DIY. Fokus penelitian untuk mengetahui problem internal sekolah yang dihadapi, tujuan yang akan dicapai, dan capaian program yang telah diperoleh, sehingga dapat digunakan sebagai dasar pengembangan sekolah mendatang secara berkelanjutan. Metode pengembangan melalui pendekatan $R \& D$ (Research and Development) yang dikembangkan oleh Borg and Gall terdiri 10 tahapan/langkah yaitu: penelitian dan pengumpulan informasi, perencanaan, membangun prarencana produk, uji pendahuluan, revisi produk, uji produk di lapangan, revisi produk operasional, uji operasional di lapangan, revisi produk akhir, dan tahap penyebaran dan pelaksanaan. Pengembangan untuk memperoleh komponen dan indikator mutu sekolah digunakan dua pendekatan, yakni teknik Delphi dan focus group discussion (FGD). Spesifikasi produk adalah model evaluasi diri yang dikembangkan berbasis teori, hasil riset, dan informasi yang dapat digunakan untuk menetapkan kinerja SMK berupa: Panduan Umum (Guideline), Instrumen, dan Panduan Pengisian Instrumen, analisis data dan hasil evaluasi.
\end{abstract}

Kata kunci: evaluasi diri SMK

\section{A MODEL OF SELF-EVALUATION FOR VOCATIONAL HIGH SCHOOLS IN DAERAH ISTIMEWA YOGYAKARTA}

\begin{abstract}
The research aims to develop a model of effective self-evaluation, to provide an accurate result and to show the advantages of implementation within the decision making. The research wass conducted in 8 vocational high schools in Yogyakarta. The focus of the research is to find the internal problems that the school encounters, the objective that the school would like to achieve and the achievements that the school has accomplished so that the research might be used as the foundation for the school development in the future. The development method by means of Research and Development $(R \& D)$ developed by Borg and Gall consists of 10 stages namely: research and information gathering, planning, pre-plan product assembling, preliminary test, product revision, field test, operational product revision, operational field test, final product revision and implementation/distribution. The development for attaining the component and the indicator of quality is obtained by means of two approaches, namely Delphi and focus group discussion (FGD). The product spesification is a model of self-evaluation being developed based on the theory, the results of research and information. Then, the items that might be used evaluating the performance of vocational high school are: Guideline, Instrument and Instrument Manual, data analysis and results of evaluation.
\end{abstract}

Keyword: Vocational High School self evaluation 


\section{PENDAHULUAN}

Era globalisasi dan pasar bebas ditandai dengan munculnya kesepakatan bersama di antara negara-negara Asia, Asia Pasific, dan Asia Tenggara. Asean Free Trade Agreement (AFTA), dan Asean Free Labour Agreement (AFLA) merupakan salah satu bentuk kerja sama kemitraan untuk menciptakan perdagangan bebas dan tenaga kerja bebas diantara negara-negara Asia Tenggara. Dengan diberlakukannya AFLA dan AFTA pada tahun 2010, perdagangan barang dan layanan jasa di antara negara anggota menjadi lancar, bebas, dan dilindungi hukum. Permasalahan yang dihadapi barang dan jasa yang dijual harus memenuhi kualitas dan harganya murah. Tenaga kerja harus memiliki kompetensi relevan dengan keahlian, mampu mengembangkan keunggulan lokal, dan bersaing di pasar global.

Sementara itu lembaga pendidikan belum bisa menghasilkan lulusan siap pakai, sesuai dengan kebutuhan dan tuntutan dunia usaha dan dunia industri (DU/DI). Meskipun usaha telah dilakukan oleh institusi pendidikan baik malalui pelatihan dan pengembangan, namun dalam kenyataan hasilnya belum sesuai dengan tuntutan lapangan kerja, kompetensi belum dapat tercapai, dan pada akhirnya banyak terjadi ketidaksesuaian (mismatch) antara kompetensi lulusan dengan keahlian yang dibutuhkan DU/DI, sehingga mengakibatkan tidak terserapnya lulusan pendidikan yang mengakibatkan terjadi penumpukan pengangguran.

Prasurvey menunjukkan bahwa evaluasi diri di sekolah tidak efektif dan tidak efisien, masih banyak yang harus diperbaiki dan dibenahi antara lain: (1) belum terciptanya budaya evaluasi diri, masih ada pimpinan sekolah kurang komit, tidak jujur, dan tidak terbuka dalam mengungkap fakta; (2) Buku Panduan Evaluasi Diri kurang fleksibel dan sulit dipahami; (3) instrumen tidak sesuai dengan kondisi perkembangan yang sangat komplek; (4) analisis data tidak memperhatikan tingkat kepentingan setiap komponen dan item pada indikator; (5) panduan analisis hasil evaluasi diri tidak disertakan langkah-langkah usaha untuk melakukan tindakan perbaikan sehingga tidak ada solusi pemecahan tarhadap hasil evaluasi diri.
Berdasarkan kendala-kendala tersebut di atas dikembangkan model evaluasi diri sebagai penyempurnaan model yang sudah ada SMK. Model evaluasi diri yang dikembangkan berisi pedoman evaluasi diri, instrumen evaluasi diri sebagai produk sekaligus instrumen penelitian untuk menetapkan tingkat pencapaian kinerja SMK. Selain itu, penelitian pengembangan ini mempunyai manfaat: (1) model evaluasi diri yang baku, yang dapat digunakan oleh pihak internal sekolah, (2) model evaluasi diri yang bersifat on going, formative, dan self evaluation, yakni sebuah perangkat evaluasi yang dapat digunakan sewaktu-waktu oleh pihak internal sekolah untuk membangun data yang akurat dan dapat dipertanggungjawabkan, sehingga dapat digunakan sebagai dasar perbaikan kinerja sekolah.

Tujuan adalah: (1) mengembangkan model evaluasi diri yang komponen dapat dijadikan indikator yang penting dan relevan untuk mengevaluasi SMK; (2) mengembangkan model evaluasi diri yang dapat mewadahi komponen-komponen dan indikator-indikator kinerja SMK dalam peningkatan kinerja secara berkelanjutan; (3) mengembangkan model evaluasi diri yang efektif dan dapat memberikan hasil evaluasi yang akurat dan memiliki presisi tinggi berupa informasi yang berharga untuk pengambilan keputusan serta dapat menunjukkan kelebihan dan bermanfaat (merit \& worth) program SMK bagi pemangku kepentingan (stakeholder).

Manfaat pengembangan secara teoretis, metodologis, dan praktis sebagai berikut: (1) secara teoretis, hasil penelitian ini menambah khasanah ilmu pengetahuan dalam evaluasi diri menyangkut studi-studi dan konsepkonsep tentang evaluasi; (2) secara metodologis, hasil penelitian ini memberikan sumbangan pemikiran alternatif bagi model-model evaluasi diri SMK dalam peningkatan kinerja secara berkelanjutan; (3) secara praktis hasil model evaluasi diri dapat membantu sekolah untuk mempercepat pencapaian standar kinerja secara nasional.

Pengertian evaluasi dari beberapa ahli pada prinsipnya saling melengkapi. Evaluasi menurut Stufflebeam (1985:69) adalah "the process for determining the degree to which these changes in behavior are actually taking place". Dapat diartikan evaluasi adalah proses menentukan derajat perubahan tingkah laku 
yang terjadi. Pengertian ini berkaitan erat dengan istilah pengukuran yang dimaknai bahwa pengukuran itu merupakan bagian dari suatu evaluasi. Gay (1981: 61) menyebutkan bahwa:

(1) evaluation is a systematic proses of collecting and analyzing data in order to determine whether, and to what degree, objectives have been or are being achieved; (2) evaluation is a systematic proses of collecting and analyzing data in order to make decision.

Kedua pernyataan tersebut memberikan pengertian bahwa dalam melakukan suatu evalausi ada suatu proses yang dilalui secara sistematis. Jadi pada dasarnya evaluasi itu merupakan suatu proses untuk sampai pada pembuatan keputusan (memberikan makna) berdasarkan data-data yang diperoleh. Evaluasi merupakan sesuatu yang kompleks dimana di dalamnya meliputi pembuatan/ pengambilan keputusan atau pertimbangan tentang ketercapaian tujuan, yang dapat didasarkan atas data kuantitatif maupun data kualitatif.

Untuk menilai dan memberikan jaminan mutu Sekolah (quality assessment and assurance), evaluasi diri yang merupakan evaluasi internal sekolah adalah langkah pertama yang hasilnya dapat digunakan untuk memutakhirkan pangkalan data sekolah dalam bentuk profil yang komprehensif, perencanaan, strategi pengembangan dan perbaikan sekolah secara berkelanjutan, penjaminan mutu internal sekolah, dan untuk mempersiapkan evaluasi eksternal.

Pengertian evaluasi diri adalah evaluasi yang dilakukan oleh institusinya sendiri, untuk mengumpulkan data, anlisis data, dan interpretasi hasil yang digunakan untuk perencanaan, pengembangan, perbaikan dan/ atau peningkatan kinerja lembaga. Ditinjau dari waktunya, evaluasi dapat dilakukan seiring dengan tahapan program yang akan dievaluasi: (1) pada tahap awal untuk perencanaan dilakukan dengan input evaluation, SWOT Analysis, atau Needs Assessment; (2) pada tahap pelaksanaan program dilakukan evaluasi proses atau formative evaluation; (3) pada tahap hasil dilakukan evaluasi hasil atau summative evaluation; (4) dan dampak kebijakan dievaluasi dengan evaluasi dampak, evaluasi tindak lanjut followup evaluation. (Soenarto, 1997: 4),
Pelaksanaan evaluasi diri dapat dilakukan dengan baik bila semua pihak (warga sekolah, sivitas akademika) yang terlibat mendukung kelancaran dan membuahkan hasil yang akurat, pimpinan harus jelas, jujur, dan terbuka dalam mengungkap fakta, penetapan indikator kinerja lembaga (sekolah) didasarkan acuan yang telah ditentukan; dan selanjutnya hasil evaluasi diri dikomunikasikan kepada pemangku kepetingan guna perencanaan sekolah berikutnya.

Prinsip implementasi evaluasi diri: berorientasi pada tujuan, mengacu pada kriteria keberhasilan, asas manfaat, dan objektif. Tujuan evaluasi diri dilaksanakan meng-acu pada tujuan yang ingin dicapai. Hasil Evaluasi diri dipergunakan sebagai bahan untuk perbaikan atau peningkatan program pada evaluasi formatif dan membuat justifikasi serta akuntabilitas pada evaluasi sumatif; (1) Mengacu pada kriteria keberhasilan; Evaluasi diri dilaksanakan mengacu pada kriteria keberhasilan program yang telah ditetapkan sebelumnya. Penentuan kriteria keberhasilan dilakukan bersama antara para evaluator, para sponsor, pelaksana program (pimpinan dan staf), para pemakai lulusan (konsumen), lembaga terkait. (2) Asas manfaat; Evaluasi Diri sudah seharusnya dilaksanakan dengan manfaat yang jelas, berupa saran, masukan atau rekomendasi untuk perbaikan programprogram yang dievaluasi atau program sejenis di masa mendatang. (3) Objektif; Evaluasi diri harus dilaksanakan secara objektif. Petugas Evaluasi Diri harus bertindak objektif, yaitu melaporkan temu-annya apa adanya. Djemari Mardapi (2007: 3),

Evaluasi diri digunakan untuk mengetahui, memahami, dan menyadari dengan baik profil suatu lembaga, termasuk mutu, dan kondisi lembaga saat ini untuk digunakan sebagai landasan bagi lembaga menentukan kondisi masa depan yang diinginkan atau dicita-citakan. Program sekolah yang direncanakan dengan baik akan dapat menemukan hasil yang sebenarnya, sehingga sekolah dapat melakukan perencanaan dan tindakan tepat untuk mencapai tujuan yang dicita-citakan. Gambar 1. merupakan ilustrasi perbedaan perkembangan SMK dengan perencanaannya menggunakan evaluasi diri dengan yang tidak menggunakan evaluasi diri. 


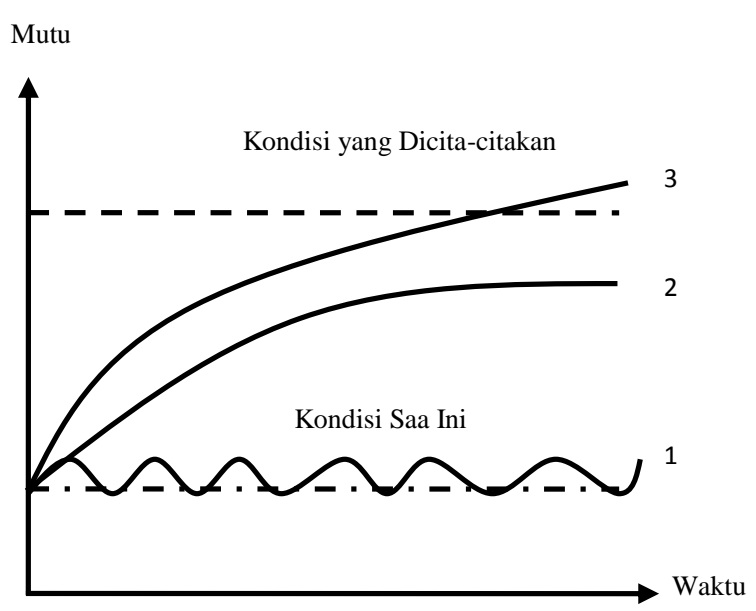

Gambar 1. Ilustrasi Perkembangan SMK (Djemari Mardapi, dkk. 2007,10)

Keterangan:

1. Perkembangan SMK tanpa melakukan evaluasi diri

2. Perkembangan SMK dengan evaluasi diri tanpa pendampingan

3. Perkembangan SMK dengan evaluasi diri dengan dukungan dana dan pendampingan

Gambar 1 menunjukkan bahwa SMK yang dikembangkan tanpa dengan evaluasi diri perkembangannya berfluktuasi dan tidak dapat mencapai kondisi yang dicita-citakan. SMK yang dikembangkan dengan evaluasi diri tetapi tidak memperoleh dukungan dari pihak luar, akan sulit berkembang menuju kondisi yang dicita-citakan. Karena itu merupakan langkah yang tepat jika Dit. PSMK memberi bantuan pengembangan SMK dan mendorong melakukan evaluasi diri, sehingga hasilnya dapat digunakan sebagai dasar untuk mengembangkan lembaga selanjutnya.

Tujuan evaluasi diri dimaksudkan untuk hal-hal berikut: (1) penyusunan profil lembaga yang komprehensif dengan data mutakhir; (2) perencanaan dan perbaikan diri secara berkelanjutan; (3) penjaminan mutu internal sekolah; (4) pemberian informasi mengenai sekolah kepada masyarakat dan pihak tertentu yang memerlukannya (stake holders); (5) persiapan evaluasi eksternal atau akreditasi dari Badan Akreditasi Nasional Sekolah/Madrasah (BAN S/M).

Implementasi evaluasi diri mengandung prinsip-prinsip: kejelasan tujuan dan hasil yang hendak dicapai, pelaksanaan dilakukan secara komprehensif, objektif, transparan, akuntabel, dan dilakukan secara profesional, partisipatif, tepat waktu, berkala, dan berkelanjutan, serta mengacu pada indikator keberhasilan kinerja. Oleh sebab itu perlu adanya suatu instrumen evaluasi diri yang komprehensif, holistik, mudah dilakukan, efektif, dan independen.

Hasil evaluasi diri yang dilakukan sebagai dokumen sekolah yang dapat digunakan untuk kebutuhan internal sekolah antara lain: penyusunan profil lembaga dengan data mutakhir, perencanaan dan perbaikan diri secara berkelanjutan, penjaminan mutu internal sekolah, pemberian informasi sekolah kepada pemangku kepentingan (stakeholders), dan untuk persiapan evaluasi eksternal atau akreditasi.

\section{Kerangka Pikir}

Kerangka pikir pengembangan model evaluasi diri sekolah berlandaskan pada yaitu: filosofis, yuridis, pemikiran, dan mekanisme.

Landasan Filosofis, bahwa pada prinsipnya pendidikan itu bisa memperbaiki diri, maka institusi sekolah harus mampu mengevaluasi dirinya sendiri, dan tanpa tahu kelemahan, kekuatan, peluang, dan ancaman, serta apa yang harus dilakukan, maka tidak bisa memperbaiki dirinya. Oleh karena itulah evaluasi diri merupakan suatu keharusan bagi institusi sekolah apabila ingin meningkatkan kualitas dirinya.

Landasan Yuridis yaitu peraturan dan perundangan yang diterbitkan pemerintah sebagai landasan meningkatkan kualitas pendidikan antara lain: Undang-Undang Nomor 20 Tahun 2003 tentang Sistem Pendidikan Nasional dan dijabarkan dalam Peraturan Pemerintah Nomor 19 Tahun 2005 tentang Standar Nasional Pendidikan, dan lebih dirinci lagi dalam Peraturan Menteri Pendidikan Nasional Nomor 23 Tahun 2006 tentang Standar Kompetensi Lulusan (Permendiknas 23/2006) yang bunyinya sebagai berikut, "Pendidikan menengah kejuruan bertujuan untuk "meningkatkan kecerdasan, pengetahuan, kepribadian, ahklak mulia, serta keterampilan untuk hidup mandiri dan mengikuti pendidikan lebih lanjut sesuai dengan kejuruannya".

Landasan Pemikiran, bahwa suatu lembaga pendidikan pasti mempunyai visi, 
misi, dan tujuan yang akan dicapai. Untuk mencapai tujuan yang dikembangkan, evaluasi diri dilaksanakan berdasarkan analisis SWOT (strengths, weaknesse, opportunities, threats) yaitu analisis didasarkan pada kekuatan, kelemahan, peluang, dan ancaman, dari empat analisis ini perlu dilengkapi dengan Intervention sehingga menjadi SWOTI. Intervention merupakan usah-usaha yang dapat dilakukan untuk mengatasi adanya kelemahan dan menghadapi adanya ancaman-ancaman yang mungkin terjadi. Lebih jelasnya dapat disajikan pada Gambar 2.

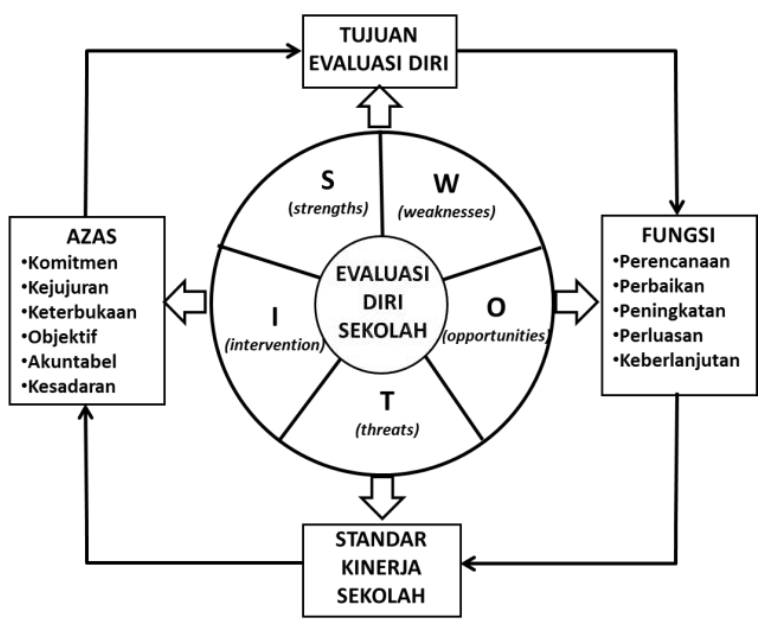

Gambar 2. Dasar Pemikiran Pengembngan Model Evaluasi Diri

Evaluasi diri mempunyai fungsi yaitu pertama fungsi sebagai Perencanaan, artinya evaluasi diri mempunyai fungsi sebagai dasar perencanaan progran masa akan datang, kedua sebagai perbaikan artinya dengan mengetahui kekuatan dan kelemahan maka dapat diperguakan sebagai dasar perbaikan, ketiga sebagai peningkatan artinya evaluasi berfungsi sebagai dasar peningkatan kualitas kinerja suatu lembaga, ke empat fungsi sebagai perluasan artinya hasil evaluasi diri berfungsi sebagai dasar pengembangan untuk memperluas diri.

Selanjutnya evaluasi diri harus ada standar yang ditetapkan. Standar tersebut harus objektif, dan independen tidak bisa dipengaruhi oleh faktor-faktor dari luar. Apabila standar tersebut tidak objektif maka hasil evaluasi tidak mengetahui kelemahan dan kelebihan yang sebenarnya, sehingga tidak bisa dijadikan sebagai dasar untuk perbaikan ke depan.
Agar evaluasi diri mendapatkan hasil yang objektif harus punya azas-azas. Azasazas evaluasi diri yang dimaksut antara lain kometmen, kejujuran, keterbukaan, objektif, dan akuntabel. Suatu institusi apabila mengungkap suatu fakta tidak jujur, tidak terbuka, tidak objektif, dan tidak akuntabel maka institusi tidak mau melihat dirinya dengan jernih, dan ada sesuatu yang ditutupi, maka apabila melakukan evaluasi diri tidak tahu kelemahan, kelebihan, peluang, dan ancaman dari dirinya, yang pada akhirnya institusi lembaga tersebut tidak bisa merencalakan program perbaikan dan pengembangan lembaga yang akan datang.

Mekanisme Pengembangan model evaluasi mencakup, Bagaimana membuat rencana dan melakukan evaluasi diri. Mekanisme didasari oleh kerangka konseptual yang logis, runtut, dan terstruktur. Ada beberapa rasional yang perlu dijelaskan dalam rangka mengembangkan model evaluasi diri kinerja SBI. Pertama, Pengembangan model evaluasi diri memaparkan segala informasi yang dimiliki oleh sekolah seperti: profil sekolah, rencana program sekolah (RPS), rencana anggaran, pendapatan, dan belanja sekolah (RAPBS), serta kelebihan dan keterbatasan kemampuan sekolah. Setelah mengetahui mekanisme selanjutnya apa yang akan dilakukan sekolah pada tahap berikutnya, lebih jelasnya disajikan pada Gambar 3.

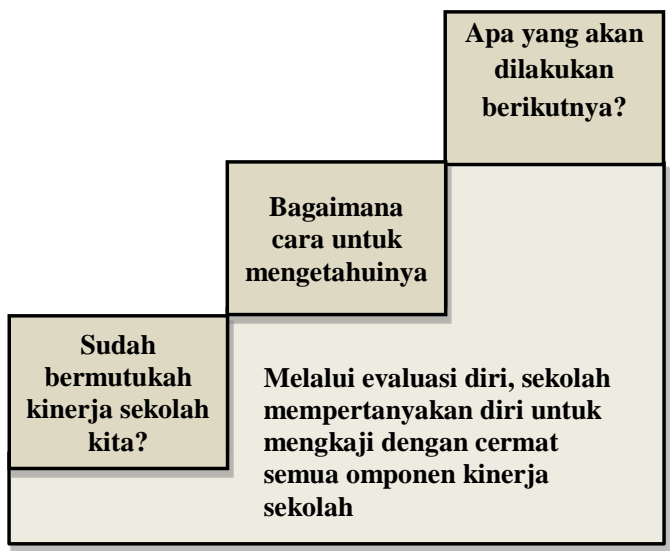

Gambar 3. Tiga Langkah Proses Evaluasi Diri Sekolah

(Sumber: Quality Assurance through School Self Evaluation, Taylor, 2005).

Kedua, warga sekolah yang terdiri atas kepala sekolah, wakil kepala sekolah, guru, siswa, staf administrasi dan orang tua siswa yang 
terhimpun dalam komite sekolah, dan forum kelas, mengenali dan memahami karakteristik kegiatan evaluasi SMK secara berkelanjutan, disajikan pada Tabel 1 .

Tabel 1. Karakteristik Kegiatan Evaluasi Mutu Sekolah

(Sumber: Depdiknas tentang Pedoman Penjaminan Mutu PT, 2005)

\begin{tabular}{llll}
\hline Kegiatan & Tujuan & Sifat & Lembaga \\
\hline Akreditasi & Kontrol dan & Wajib & Basnas \\
Sekolah & $\begin{array}{l}\text { Audit Mutu } \\
\text { Pendidikan }\end{array}$ & & $\begin{array}{l}\text { (Asesor } \\
\text { Diknas) }\end{array}$ \\
& Secara & & \\
& Eksternal & & \\
Evaluasi & Pembimbingan, Wajib & Diknas \\
Program & Pendampingan & & (Pengawas \\
Sekolah & dan Pembinaan & & Sekolah) \\
Berbasis & Sekolah & & \\
Evaluasi & & & \\
Diri & & & \\
Evaluasi & Evaluasi & Inisiatif & Komite \\
Mutu & Berkelanjutan/ & Sekolah & Sekolah \\
Sekolah & Evaluasi & On & (Kepala \\
& Formatif & Going & Sekolah, \\
& & & Guru, Siswa, \\
& & Ortu) \\
\hline
\end{tabular}

Ketiga, Mekanisme langkah yang harus dijawab oleh internal sekolah adalah: (1) dimanakah posisi sekolah sekarang dan sejauh mana telah dilakukan; (2) apa yang terpenting untuk diperhatikan; (3) apa rencana untuk memperbaiki kinerja sekolah; dan (4) bagaimana kalau telah mendapatkannya. Selanjutnya setelah sekolah mendapatkanya maka dipertanyakan kembali ke langkah (1) dan seterusnya, dilakukan secara menerus berkelanjutan.

\section{METODE}

Prosedur pengembangan diterapkan menggunakan sepuluh langkah utama dalam research and development (R\&D) Borg dan Gall (1989: 784). Sepuluh langkah di atas dioperasionalkan dalam kegiatan penelitian dan pengembangan yaitu sebagai berikut.

\section{Langkah 1: Research and Information Collecting}

Tahap penelitian dan pengumpulan informasi, tahap ini informasi dikumpulkan melalui observasi langsung di lapangan, studi pustaka, kajian model yang sudah ada. Data dari pihak-pihak institusi terkait fungsinya karena dapat mengetahui gambaran dalam menentukan rancangan model sehingga rancangan model dengan mudah menyesuaikan keadaan di lapangan. Informasi data diharapkan mendapatkan: (a) beberapa model evaluasi diri, dan (b) berbagai komponen dan indikator kinerja SMK. Observasi ke sekolah dan interview ke berbagai sumber data di sekolah diperoleh: (a) profil dan potret sekolah, (b) berbagai masalah yang dihadapi sekolah dalam perbaikan dan peningkatan kinerja sekolah, dan (c) upaya sekolah dalam memperbaiki mutu. Selanjutnya, dilakukan diskusi panel yang difokuskan pada komponen dan indikator kinerja evaluasi diri dengan pihak internal sekolah, seperti: kepala sekolah, para wakil kepala sekolah, guru, dan pihak eksternal sekolah, seperti: pengawas sekolah, dan pakar pendidikan. Tujuan utama pada kegiatan ini untuk mendapatkan draf komponen dan indikator kinerja evaluasi diri di SMK.

\section{Langkah 2: Planning}

Tahap perencanaan, merencanakan langkah-langkah dari R\&D. Aspek penting dari tahapan perencanaan di sini adalah menetapkan tujuan yang spesifik tentang apa yang ingin dihasilkan oleh produk pengembangan. Tujuan dari perencanaan produk pengembangan adalah dihasilkannya draf komponen evaluasi diri, panduan umum evaluasi diri, instrumen dan panduan pengisian instrumen, menyusun software pengolah data dan panduan penggunaannya, serta panduan penyajian informasi hasil evaluasi diri.

\section{Langkah 3. Develop Preliminary Form of Product}

Setelah tahap perencanaan selesai, langkah utama selanjutnya adalah membangun bentuk pendahuluan dari produk pengembangan yang dapat diujicobakan di lapangan. Pada langkah ini, draf instrumen model evaluasi diri yang telah dikaji melalui diskusi panel (focus group discussion) dengan pengguna produk pengembangan SMK, dan pengawas sekolah, serta dengan para pakar pendidikan. Hasil akhir dari langkah ke tiga 
adalah prototipe model evaluasi diri yang siap untuk dilakukan uji coba pendahuluan.

\section{Langkah 4. (Preliminary Field Testing)}

Pada langkah ke empat, uji lapangan pendahuluan dimaksudkan untuk memperoleh informasi awal tentang model evaluasi diri, dilakukan evaluasi kualitatif tentang produk baru "model evaluasi diri". Pada tahap uji coba pendahuluan ini melibatkan 10 orang subjek coba yang dipilih secara purposive terdiri atas lima pakar pendidikan, dan praktisi pendidikan yang terdiri atas tiga kepala sekolah, dan dua pengawas sekolah. Pada uji coba pendahuluan ini fokus kegiatan untuk memilih aspek-aspek, komponen-komponen yang akan dievaluasi prosedur evaluasi, personal yang melakukan evaluasi, karena yang akan dikembangkan adalah model evaluasi diri.

\section{Langkah 5. Main product revision}

Pada langkah kelima, dikatakan sebagai revisi produk utama, dimana prototipe produk pengembangan berupa instrumen evaluasi diri yang berisi komponen dan indikator kinerja SMK diperbaiki berdasarkan masukan-masukan dari uji coba pendahuluan. Hasil revisi pada langkah ini digunakan sebagai bahan untuk uji coba ke dua, yakni uji coba lapangan utama yang dilakukam pada langkah keenam.

\section{Langkah 6. Main Field Testing}

Tahap uji coba yang kedua dikatakan sebagai uji coba hasil pruduk. Pada tahap ini, prototipe produk pengembangan diharapkan sudah lebih baik dan siap diujicobakan pada skala yang lebih luas. Pada tahap uji coba utama dilaksanakan kepada 20 orang subjek coba yang terdiri atas dua kepala sekolah, enam wakil kepala sekolah, empat guru, empat siswa, dandua orang komite sekolah di SMK Negeri 1 Depok Sleman dan SMK Negeri 1 Kalasan.

\section{Langkah 7. Operational Product Revision}

Langkah ketujuh berupa revisi produk operasional, di mana prototipe produk pengembangan berupa instrumen evaluasi diri SMK yang berisi komponen dan indikator evaluasi diridan panduan diperbaiki berdasar- kan masukan-masukan dari uji coba lapangan utama kedua. Hasil revisi pada langkah ini digunakan sebagai bahan untuk uji coba ke tiga atau uji coba lapangan operasional sebagai uji coba terakhir.

\section{Langkah 8. Operational Field Testing}

Tahap uji coba yang ketiga dikatakan sebagai operational field testing atau uji coba operasional diterapkan pada 30 orang subjek coba. Pada tahap ini, produk pengembangan berupa pedoman umum, instrumen dan pedoman pengisian instrumen, program analisis data, dan pedoman pelaporan hasil evaluasi diri kinerja SMK. Langkah ini dapat mengungkap data dan informasi yang valid dan reliabel tentang kondisi riil di sekolah, serta harapan dan upaya yang telah, sedang, dan akan dilakukan oleh warga sekolah, mulai kepala sekolah, wakil kepala sekolah, para guru, dan siswa, dan komite sekolah.

Uji coba ketiga melibatkan 30 orang subyek coba terdiri dari tiga kepala sekolah, sembilan wakil kepala sekolah, enam guru, enam siswa, dan tiga komite sekolah. Uji coba ketiga atau uji coba operasional ini dilakukan ditiga sekolah yaitu SMK Negeri 2 Pengasih, SMK Negeri 2 Wonosari, dan SMK Muhammadiyah 3 Yogyakarta.

\section{Langkah 9. Final Product Revision}

Pada langkah kesembilan, dikatakan sebagai revisi produk akhir. Produk pengembangan berupa instrumen evaluasi diri SMK diperbaiki berdasarkan masukan-masukan dari uji coba operasional, baik masukan dari subjek coba pada langkah kedelapan juga masukan dari para pakar. Hasil revisi pada langkah ini merupakan uji coba terakhir dari langkah-langkah $\mathrm{R} \& \mathrm{D}$, sehingga produk pengembangan dapat dikatakan sebagai produk akhir dalam bentuk model evaluasi diri SMK. Produk yang dihasilkan adalah panduan evaluasi diri, instrumen kinerja SMK, adalah instrumen evaluasi diri kinerja SMK berisi: Angket Kepala Sekolah, Angket Wakil Kepala Sekolah, Angket Guru, Angket Siswa, Angket Pengawas, dan daftar Dokumentasi sekolah, dan Panduan wawancara dengan Kepala Sekolah, Guru, Siswa, dan staf tenaga kependidikan. 


\section{Langkah 10. Dissemination and Implementation}

Langkah R\&D seringkali dikatakan sebagai proses yang membutuhkan waktu sangat panjang. Diseminasi mengarahkan pada proses untuk membantu kemungkinan pengguna menjadi tahu atau mengerti dari produk R\&D ini. Implementasi mengarahkan pada proses untuk membantu menyetujui produk $\mathrm{R} \& \mathrm{D}$ digunakan pada sekolah yang diharapkan. Diseminasi dan implementasi produk pengembangan dilakukan di beberapa sekolah SMK di Daerah Istimewa Yogyakarta, baik sekolah yang digunakan sebagai uji coba produk maupun sekolah lainnya yang tidak digunakan sebagai uji coba produk pengembangan.

\section{SIMPULAN}

Berdasarkan hasil penelitian dan pengembangan dapat disimpulkan bahwa Model Evaluasi Diri SMK.

Pertama; Komponen dan indikator evaluasi diri kinerja sekolah merupakan inti (core) dari Model Evalusi Diri SMK. Hal ini disebabkan komponen dan indikator kinerja sekolah dikembangkan para pakar dan praktisi pendidikan berdasarkan kajian konseptual, kajian teoretik, dan pengalaman empirik di lapangan melalui survai, FGD.

Kedua: Ada interaksi yang positif antarpakar pendidikan dan praktisi pendidikan dalam memberikan penilaian (judgment) komponen dan indikator kinerja sekolah. Proses pengembangan Model Evaluasi Diri Sekolah yang di dalamnya berisi 10 komponen dan 39 indikator kinerja sekolah merupakan kesepakatan bersama yang dikembangkan sebagai instrumen evaluasi diri SMK.

Ketiga; Model Evaluasi Diri Sekolah hasil pengembangan memiliki kepekaan yang tinggi terhadap obyek yang diteliti. Hal ini disebabkan dalam proses uji coba pendahuluan, utama, dan operasional di delapan SMK yang melibatkan 60 orang subjek coba dapat mengungkap data yang dibutuhkan.

Keempat: Model Evaluasi Diri Sekolah hasil pengembangan dapat memberikan informasi yang tepat bagi stakeholder ketika digunakan untuk melihat kelebihan dan bermanfaat (merit \& worth) peningkatan sekolah berkelanjutan. Empat jenis instrumen yang digunakan meliputi angket, dokumentasi, observasi, dan wawancara, dapat memberikan seluruh informasi yang berkaitan dengan implementasi komponen dan indikator kinerja sekolah, termasuk yang dilakukan siswa, guru, kepala sekolah, dan komite sekolah.

Kelima; Model Evaluasi Diri Sekolah ketika diimplementasikan untuk acuan menetapkan tingkat kinerja sekolah memiliki kecocokan (koherensi) dengan rancangan. Empat jenis instrumen yang digunakan untuk menggali data dapat memberikan informasi yang saling mendukung dan melengkapi antara data kuantitatif yang dianalisis dengan statistik deskriptif maupun data kualitatif yang dianalisis dengan metode interaktif.

Keenam; Kelebihan Model Evaluasi Diri Sekolah hasil R\&D dibandingkan dengan instrumen evaluasi diri yang sudah ada. Karena mempunyai karakteristik yakni: (a) komprehensif, karena komponen dan indikator mewakili hampir seluruh kegiatan penyelenggaraan pendidikan; (b) holistik, karena dapat mengungkap fakta sesungguhnya apa yang terjadi di sekolah; (c) mudah dilakukan; (d) temuan Model Evaluasi Diri Sekolah dapat digunakan sebagai evaluasi diri sekolah; (e) efektif digunakan sekolah tanpa mengganggu proses pembelajaran yang ada; (f) mendukung persiapan akreditasi sekolah dan penjaminan mutu; serta $(\mathrm{g})$ independen karena melibatkan komite sekolah.

\section{Implikasi}

1. Hasil pengembangan model memberi implikasi bahwa Model Evaluasi Diri Sekolah dengan perangkat instrumennya telah teruji di lapangan dengan fit, dapat menambah ragam model evaluasi diri, memperkaya khazanah ilmu pengetahuan di bidang evaluasi pendidikan. Instrumennya, dapat memperkaya koleksi instrumen, dapat dirujuk sebagai acuan peneliti lain di SMK maupun instansi lain.

2. Hasil penelitian ini dapat memberikan keunggulan dan bermanfaat kepada berbagai pihak terutama sebagai umpan balik kepada institusi SMK sebagai dasar pe-ngembangan sumberdaya manusia/ non-manusia, organisasi dan menagemen, kepemimpinan kepala sekolah, kinerja guru, pengawas, dukungan unsur terkait, motivasi siswa selanjutnya. 
3. Hasil pengembangan model memberikan wawasan pengetahuan dan pengalaman yang lebih baik bagi penulis yang dapat dijadikan landasan berpikir untuk menindaklanjuti hasil penelitian ini dengan bekerja sama Dinas Pendidikan Nasional Kabupaten dengan memanfaatkan model untuk mengembangkan evaluasi diri selanjutnya.

4. Model Evaluasi Diri Sekolah ini mendukung sekolah dalam penyusunan profil lembaga, perencanaan, dan perbaikan diri secara berkelanjutan, penjaminan mutu internal sekolah, dan persiapan evaluasi eksternal atau akreditasi dari Badan Akreditasi Nasional Sekolah (BANS).

\section{Saran}

1. Pedoman Model Evaluasi Diri Sekolah dapat dijadikan sebagai alternatif bagi otoritas pendidikan di SMK seperti kepala sekolah, wakil kepala sekolah, guru, siswa, komite sekolah, koordinator SMK, dan tenaga pendukung lainnya dalam melakukan evaluasi diri kinerja sekolah. Hanya saja diperlukan daya analisis kritis para evaluator dalam melakukan evaluasi diri sekolah dalam kesadaran, kejujuran, komitmen, dan konsistensi yang tinggi.

2. Pedoman Model Evaluasi Diri Sekolah untuk SMK ini dapat dikembangkan lebih lanjut agar menjadi lebih sempurna. Hal ini karena adanya keterbatasan pada: (a) proses evaluasi belum pernah didesiminasikan ke publik sehingga banyak otoritas pendidikan di sekolah (Kepala Sekolah, Komite Sekolah, Pengawas Sekolah, Ketua MKKS dan MGMP) belum mengenal karakteristik dan penerapan di SMK Negeri maupun Swasta; (b) menggunakan banyak instrumen pengumpulan data sehingga harus melibatkan banyak personel gugus tugas dalam pelaksanaannya; dan (c) membutuhkan waktu yang panjang karena banyaknya data dan informasi yang harus diungkap untuk keperluan analisis.

3. Pada prinsipnya, Pedoman Evaluasi Diri Sekolah dapat digunakan untuk melakukan evaluasi diri di samping SMK juga dapat digunakan pada jenis sekolah yang lain. Yang perlu diperhatikan adalah elaborasi komponan dan indikator kiner- janya untuk disesuaikan dengan karakteristik SMK/MA.

4. Untuk mendapatkan data dan informasi yang akurat di SMK, jumlah subjek coba dapat diperluas secara proporsional, baik guru, siswa, dalam tingkatan jumlah maupun bidang keahliaanya serta komitmen tinggi, informasi akurat, jujur, dan konsisten.

5. Model Evaluasi Diri Sekolah untuk SMK ini hanya menggunakan 10 komponen dan 39 indikator kinerja sekolah, akan lebih komprehensif apabila model ini dapat dikembangkan lebih lanjut melalui delphi tiga putaran dan melibatkan subjek coba sekolah yang lebih banyak serta memperbesar jumlah peserta dalam forum diskusi panel dan FGD agar diperoleh komponen dan indikator mutu yang lebih spesifik.

\section{DAFTAR PUSTAKA}

Depdiknas. (2003). Undang-undang Republik Indonesia nomor 20 tahun 2003 tentang sistem pendidikan nasional. Jakarta: Sekneg.

Depdiknas. (2010). Pedoman evaluasi diri program studi. Jakarta: Badan Akreditasi Nasional Perguruan Tinggi Departemen Pendidikan

Djemari Mardapi. (2006). PemantauanEvaluasi (Pe) LPMP dan PPPG. Laporan Penelitian. Subdit Pengembangan Sarana Diklat Ditbindiklat. Ditjen PMPTK Depdiknas. Jakarta.

Gall, M. D. .\& Borg, W. R. (1989). Educational research: an introduction. Fifth edition. New York: Longman.

Gay, L. R. (1990). Educational research: competencies analysis and aplication. (3nded. ) edition. Columbus: Charles E. Merrill Publishing.

Heimo K. (2004). Self-evaluation workbook for local action groups. Helsinki: Ministry of Agriculture and Forestry.

Husaini Usman. (2004). Manajemen Pendidikan.Yogyakarta: PT Bumi Aksara.

Sallis, E. (2002). Total quality management in education. (3rd ed.) London: Kogan Page Ltd 
Sarbiran. (2005). TQM in Education Manajemen Mutu untuk Pendidikan. Yogyakarta: PPS Universitas Negeri Yogyakarta. Yogyakarta: FPTK IKIP Yogyakarta.

Soenarto,dkk. (2007). Program Pendampingan Evaluasi Diri SMK-BI 2007. Laporan Penelitian. Kerjasama Program Pascasarjana UNY dengan Dit PSMK Depdiknas. Jakarta.
Soenarto, dkk. (2007). Verifikasi SMK-IGI SBI 2007. Laporan Penelitian. Kerjasama Program Pascasarjana dengan UNY-IGI Dit PSMK Depdiknas. Jakarta

Stufflebeam, D. L. \& Shinkfield. A. J. (1985). Systematic evaluation. Boston: Kluwer Nijhof Publishing. 